\title{
Fechtner Syndrome
}

National Cancer Institute

\section{Source}

National Cancer Institute. Fechtner Syndrome. NCI Thesaurus. Code C131642.

An autosomal dominant disorder characterized by the triad of thrombocytopenia, giant platelets, and characteristic inclusions in peripheral blood leukocytes, with the additional features of nephritis, hearing loss, and eye abnormalities, mostly cataracts; it is associated with mutation of the MYH9 gene. 